[Radiocarbon, Vol.. 9, 1967, P. 316-332]

\title{
OHIO WESLEYAN UNIVERSITY NATURAL RADIOCARBON MEASUREMENTS III
}

\author{
J. GORDON OGDEN, III and RUTH J. HAY
}

Department of Botany and Bacteriology, Ohio Wesleyan University

Delaware, Ohio

\section{INTRODUCTION}

The following list of dates is compiled from samples prepared since publication of our last date list (OWU II) and includes determinations through November, 1966. Equipment and operating procedures are the same, except that the sample conversion system has been altered to include a second vacuum pumping system and a separate oxygen/nitrogen combustion train.

Unless noted otherwise, all samples are pre-treated with hot $2 \%$ $\mathrm{NaOH}$ and $10 \% \mathrm{HCl}$. Samples of archaeological charcoal are subjected to an additional pre-treatment to remove rootlet cellulose following the method of Haynes (1966). Purity of sample $\mathrm{CO}_{2}$ and $\mathrm{CH}_{4}$ is checked with a gas chromatograph. Methane samples are stored for one month to permit decay of radon before counting.

Ages are quoted with a lo counting error which includes the statistical variation of the sample count as well as that for background and for the contemporary standard. The half-life value is $5568 \mathrm{yr}$, and the reference year is 1950 .

Sample processing techniques have been tested in the following samples: OWU-105, 139, 140, 142, 143, 144, 166, 168, 177, 200, and 224.

\section{ACKNOWLEDGMENTS}

The support of the National Science Foundation (GB-3416) is gratefully acknowledged. Thanks are due to Prof. G. W. Burns and Mr. K. E. Phillips of Ohio Wesleyan University for identification of wood samples described in this report. Miss Gail Garrison performed many of the pollen analyses associated with the samples.

\section{SAMPLE DESCRIPTIONS}

I. GEOLOGIC SAMPLES-GLACiAL GEOLOGY

\section{OWU-140B. Ross Well, Cincinnati, Ohio 22,840 B.C.}

$24,790 \pm 780$

Spruce wood (id. by G. W. Burns) from 90 to $91 \mathrm{ft}$ below surface in Wisconsin outwash gravel at Ross Well 3, on Nat. Lead Co. property of U.S.A.E.C. reservation (39 $18^{\prime} \mathrm{N}$ Lat, $84^{\circ} 42^{\prime} \mathrm{W}$ long). Sample impregnated with crystals of $\mathrm{CuSO}_{4}$, and two previous samples (OWU-140 and OWU-140A) were rejected because of sulfur poisoning of the ruthenium catalyst in methane reactor. OWU-140B was pre-treated at $500^{\circ} \mathrm{C}$ in stream of nitrogen and all sulfur was apparently distilled off, as there was no discoloration of $\mathrm{MnO}_{2}$ trap during combustion, and 
methane yield was $97 \%$. Coll. 1963 and subm. by J. L. Forsyth. Comment (J.L.F.): date is older than almost all late Wisconsin radiocarbon dates from Ohio; it is approx. same age as oldest late Wisconsin date from wood in proglacial lake deposit in Cleveland. Ross well wood came from thick deposit that is clearly glacial outwash, here covered by segment of Hartwell Wisconsin terminal moraine, whose till has been clated at 17 to $20,000 \mathrm{yr}$ at other places in Butler County (W-304, W-92, W-724, $\mathrm{W}-738, \mathrm{Y}-450$, OWU-102). Therefore, ice must have advanced $\mathrm{S}$ earlier in western Ohio than in eastern, and ice must have reached $S$ of Ohio divile (located along a line through Wapakoneta, Kenton, Bucyrus, and Wadsworth) in order to have permitted such thick accumulation of outwashı down river at time of date.

\section{OWU-141. Johnstown Mastodon, $10,190 \pm 160$} Spruce wood (id. by

mastiodon $\left(40^{\circ} 9^{\prime}\right.$. K. H. Wickham. Comment (J.G.O. III): although 1926 and subm. by recorded at time of emment (J.G.O. III): although stratigraphy was not and tored with other mas retained by K. H. Wickham sample for dating, pollen anabilia of the occasion. Prior to accepting wood. Pollen spectrum showel pris was run on blue clay adhering to grass pollen with less than $3 \%$ of deciduous tree pollen pine, sedge, and birch Pollen ex ollen (oak, elm, and birch). Pollen extracted from resins and tars trapped in teeth of another mastodon recently discovered near this site (OWU-194, this clate list) is this mastodon find ans and Ambrosia-type. Pollen spectra and dates of that reported for 0 aWU-126 (OWU (this date list) are closely similar to ion of Johnstown tion of Johnstown mastodon attracted considerable attention, as animal was been reconstructed and is now a featured exhibit at Cleveland Mus. of Nat. History.

\section{OWU-159. Todd Fork, Clinton County, $21,140 \pm 1435$}

OWU.160. Todd Fork, Clinton County, Ohio $\quad 22,255 \pm 1650$

Both are samples of spruce wood (id. by K. E. Phillips) and are from mid-Wisconsin "forest bed" just $\mathrm{N}$ of Wisconsin terminal moraine near Sligo, Ohio (39॰ $25^{\prime} \mathrm{N}$ Lat, $83^{\circ} 55^{\prime} \mathrm{W}$ Long). Expected to date burial of forest bed by advance of late Wisconsin ice. Samples were small and provided only enough gas to count at $1 \mathrm{~atm}$ in 500-ml counter. Coll. 1964 and subm. by J. L. Forsyth. Comment (J.L.F.): dates, from within the Cuba Moraine, are from wood from noncalcareous, organic-rich, molluscbearing, silty clay, underlain by calcareous gravel and covered by first sand and gravel and then calcareous till. Upper part of till is dated at 18,500 (Y-448) near Cuba; at Clarksville, $3 \mathrm{~m}$ downstream, till (Illinoian?) beneath gravel in valley yielded wood dated at $>37,000$ 
(Y-473-1). On basis of finite dates, Cuba Moraine is clearly composite, with an earlier advance 22,000 yr ago and a later advance approx. 18,000 yr ago. This is in agreement with studies in Harveysburg area to NW by Teller (unpub. masters' thesis, Ohio State Univ.) that Scioto-lobe ice here advanced first, its deposit being overridden, after retreat, by Miami Ice Lobe, whose terminal moraine (Hartwell) was subsequently channeled by escaping meltwaters from later Scioto advance.

\section{Two Creeks, Wisconsin}

Two Creeks Forest Bed on Lake Michigan (44 $19^{\prime} 30^{\prime \prime} \mathrm{N}$ Lat, $87^{\circ}$ $33^{\prime} 0^{\prime \prime}$ W Long) was visited during Field Conf. C of 7 th INQUA Cong. in August, 1965. Samples of peat and wood from forest bed were coll. and subm. by J. G. Ogden, III.

OWU-165. Two Creeks Peat

$$
\begin{gathered}
10,680 \pm 210 \\
8730 \text { в.c. } \\
10,770 \pm 100 \\
8820 \text { в.c. }
\end{gathered}
$$

OWU-166A. Two Creeks wood (Picea)

Standard pre-treatment plus pyrolysis

\section{OWU-166B. Two Creeks wood}

$8410 \pm 170$

Standard pre-treatment

At this location (stop 8.1, INQUA Guidebook, Field Conf. C, Black and Reed, 1965). Two Creeks forest bed is $7 \mathrm{~m}$ above lake level. $100 \mathrm{~m}$ to $\mathrm{N}$ bed dips below present level of lake. $200 \mathrm{~m}$ to $\mathrm{S}$, forest bed dips to $3 \mathrm{~m}$ above lake and $500 \mathrm{~m}$ further $\mathrm{S}$ forest bed is below present level of Lake Michigan. Soils of Two Creeks horizon are of humic gley type, and are believed to have been contorted by post-depositional deformation. Stratigraphic section at site of collection is given below (Two Creeks Forest Bed, NE 1/4 NE 1/4 Sec. 2, T21 N, R 25E, Two Creeks Twp., Manitowoc Co., Wisc.; Kewaunee 15' quadrangle):

7. Modern soil, sandy, yellowish, leached in upper part

6. Indistinctly laminated sand, iron-stained

$61 \mathrm{~cm}$

5. Red clay till (Valders) greyish in lower part due to incorporated organic matter

4. Indistinctly laminated brownish lake sand

3. Two Creeks forest bed and soil (OWU-165 and 166)

$183 \mathrm{~cm}$

2. Laminated greyish lacustrine sand

1. Gray-brown lacustrine silts (Lake Chicago)

$152 \mathrm{~cm}$

$91 \mathrm{~cm}$

$65 \mathrm{~cm}$

$122 \mathrm{~cm}$

$508 \mathrm{~cm}$

Total section to Lake level

$1182 \mathrm{~cm}$

Comment (J.G.O. III): numerous age determinations of Two Creeks forest bed have been reviewed by Broecker and Farrand (1963), and indicate an average age of 11,850 yr. Numerous roots were observed in both peat and wood (OWU-165 and -166). OWU-165 and OWU-166A were given standard pretreatment of boiling and leaching in $\mathrm{NaOH}$ and 
$\mathrm{HCl}$, followed by charring in a stream of nitrogen at $500^{\circ} \mathrm{C}$. OWU $-166 \mathrm{~B}$ received only standard pre-treatment of $\mathrm{NaOH}$ and $\mathrm{HCl}$. The difference between OWU-166A and OWU-166B is probably due to presence of rootlets in OWU-166B.

Our dates being approx. $1000 \mathrm{yr}$ younger than average of 11,850 calculated by Broecker and Farrand may be due to incomplete removal of rootlet cellulose, or to location of this deposit on a topographic high, and to possibility that location was flooded later than sites previously sampled. Further experiments with pyrolysis of contemporary roots in samples of known age are being conducted and will be described in subsequent reports.

\section{OWU-167. Sangamon Peat, Wapello, Iowa}

line, of Wapello $41020^{\prime} \mathrm{W}$, Louisa County, Iowa ca. $3 \mathrm{mi} \mathrm{N}$ and $1 \mathrm{mi} \mathrm{W}$ be found in Guidebook to Field stop 13.1. Schoewe (1920) considered peat to be Sangam Reed, 1965), as the high terrace of considers high te Illinoian. Schaffer (1954) make a Farmdalian of Lake Calvin to be Tazewell in age which would make a Farmdalian correlation more probable for this peat. Coll. and subm. by J. G. Ogden, III. Comment (J.G.O. III): similar sample from this cleposit has been dated by Isotopes, Inc. (I-1865) 23,750 $\pm 600 \mathrm{yr}$. B.P. (R. V. Ruhe, personal commun.). Age clearly indicates a Farmdalian peat, and it is therefore probable that correlative high terrace of Lake Calvin is Wisconsin in age as Schaffer inferred.

\section{Castalia Prairie, Ohio}

Moss (Drepanocladus fluitans) collected at base of marl peat in Castalia Prairie (41 $24^{\prime} \mathrm{N}$ Lat, $82^{\circ} 49^{\prime} \mathrm{W}$ Long) and believed to be correlative with Lake Lundy time (Sears, 1966). Sample contained numerous shells of small gastropods. Sample $168 \mathrm{~B}$ is a re-run with addicional HCl treatment to insure digestion of shell and marl carbonates. Coll. 1964 and subm. by P. B. Sears.
OWU-168A. Castalia moss
$13,530 \pm 420$
Incomplete pre-treatment
11,580 в.C.

\section{()WU-168B. Castalia moss \\ (iarbonate-free}
12,840 B.C. $14,790 \pm 420$
Comment (J.G.O. III): oldest post-till dates in early Lake Erie basin are $\mathrm{W}-198,14,300 \pm 450$ on wood from depression in Wabash moraine of eastern Indiana; $W-33,13,360 \pm 500$ from Cleveland area; and $W-430$, $12,920 \pm 400$ from $S$ of Sandusky, Ohio (Goldthwait et al, 1965). Al- 
though OWU-168 is a "possible" date, it implies a rate of ice retreat greater than generally accepted (Goldthwait et al., 1965). Presence of marl carbonates may indicate incorporation of limestone carbonate into moss, organic matter of which is an aquatic species.

\section{Lake Tasersiaq series, western Greenland}

Samples coll. in connection with investigation of recent glacier activity in vicinity of Lake Tasersiaq, western Greenland $\left(66^{\circ} 11^{\prime} \mathrm{N}\right.$ Lat, $50^{\circ} 44^{\prime} \mathrm{W}$ Long) during the 4 th Sukkertoppen expedition.

OWU-169. Upper Valley Bog. VP-2.1: $8-13 \mathrm{~cm}$

$190 \pm 70$

\section{OWU-170. Upper Valley Bog. VP-2.1: $50-55 \mathrm{~cm}$}

\section{A.D. 1760}

$$
\begin{aligned}
& 1810 \pm 100 \\
& \text { A.D. } 140
\end{aligned}
$$

Bog in shallow upland basin $4 \mathrm{~km}$ from ice front. Stratigraphy included $55 \mathrm{~cm}$ of fibrous peat with black band at 8 to $13 \mathrm{~cm}$ (OWU-169). Brown fibrous peat at 50 to $55 \mathrm{~cm}$ overlay $10 \mathrm{~cm}$ of grey-brown sand which graded into yellow silty sand. Coll. July 1965 and subm. by G. H. Crowl and J. G. Ogden, III. Comment (J.G.O. III): samples collected to see if "Little Ice Age" glacier advance produced significant environmental changes in vicinity of Lake Tasersiaq. Although OWU-169 is from black zone in peat, and age is appropriate for Little Ice Age activity pollen and sediment analysis are inconclusive for inferring environmental conditions significantly different from the present.

Black fibrous peat from $53 \mathrm{~cm}$ below surface in a frost wedge covered by $16 \mathrm{~cm}$ of wind-blown sancl. Coll. July, 1965 and subm. by G. H. Crowl and J. G. Ogden, III. Comment (J.G.O., III): sample apparently dates last major period of ground ice activity. Soil in area is stable at present.

\section{OWU-178. Middle Moraine M4.1 : $5-8 \mathrm{~cm} \quad$ A.D. $1690 \pm 170$}

OWU-179. Middle Moraine M4.1 : $15-20 \mathrm{~cm}$ A.D.1645

Samples from soil pit in shallow depression on $\mathrm{N}$ flank of Middle Moraine $1.5 \mathrm{~km}$ from ice front. Stratigraphy at sampling site: 0 to $4 \mathrm{~cm}$, black sandy moss peat; 4 to $8 \mathrm{~cm}$, greyish-black moss peat (OWU-178); 8 to $11 \mathrm{~cm}$, brown sand with some roots; 11 to $15 \mathrm{~cm}$, grey-brown sand; 15 to $20 \mathrm{~cm}$ black/brown banded peat with grey sand lenses (OWU-179); 20 to $45 \mathrm{~cm}$, grey sand with black streaks. Coll. July, 1965 and subm. by G. H. Crowl and J. G. Ogden, III. Comment (J.G.O. III): although underlying moraine is clearly older than Little Ice Age, similarity of two 
date's implies considerable solifluction activity during Little Ice Age time. Soil in area is apparently stable at present.

\section{OW U-194. Cole Mastodon. New Chambersburg, $\quad 9460 \pm 305$ Ohio

Spruce wood (id. by G. W. Burns) from excavation of mastodon neal New Chambersburg, Ohio (40 $47^{\prime} \mathrm{N}$ Lat, $81^{\circ} 2^{\prime} \mathrm{W}$ Long). Although wood is not clearly associated with death of mastodon, date may be regarded as minimum since pollen analysis of enclosing blue clay gyttja indicates environment of spruce, fir, pine, and birch. Scrapings of teeth of mastodon showed high pollen percentages of spruce, with some pine. grass, and composites. Coll. May 1964 by W. Cole; and subm. by R. S. Baby.

\section{OWU.220. Pontius Farm Mastodon, Hallsville, $\quad 13,180 \pm 520$ Ohio$$
11,230 \text { в.c. }
$$

Spruce wood (id. by G. W. Burns) from marl deposit associated with mastodon (Mastodon americanus) remains on Orval Pontius farm near

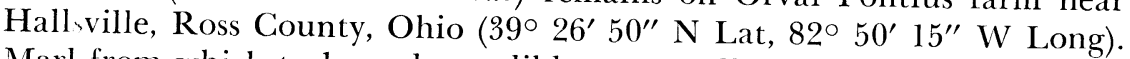
Marl from which tusks and mandibles were collected included abundant molluscan fossils, ostracods, and oogonia of Chara sp. Pollen analysis of the narl by R. Taggart of Ohio Univ. showed $64 \%$ spruce, $16 \%$ pine, $8 \%$ fir, $4 \%$ larch, $2 \%$ oak, and unknown and miscellaneous $6 \%$. Coll. Aug. 1965, and subm. by M. C. Hansen. Comment (J.G.O. III): this animal is one of several known from this locality. Age is consistent with pollen flora of site. Fluted points have been recovered near shores of extinct lake marked by marl deposits, but none have been found in association with any animal remains (O. H. Prufer, pers. commum.).

\section{$5490 \pm 235$ 3540 B.C. \\ OWL -224B Whitaker Mammoth, Alliance, Ohio $\quad 5560 \pm 245$ 3610 B.c.}

P'eaty gyttja with plant rootlets overlying grey clay gyttja associated with the right fore-limb, skull, and tusks of a mammoth (Mammut sp) from excavation near Alliance, Ohio (40 $53^{\prime} \mathrm{N}$ Lat, $81^{\circ} 8^{\prime} \mathrm{W}$ Long). Coll. Sept. 1965 by L. Whitaker; and subm. by W. A. Rice. Comment (J.G.O. III): pollen studies of overlying peat and clay gyttja in which remains were found, and scrapings from dental ridges of teeth indicate that animal was buried prior to formation of peaty material that was used for dating purposes. Virtually none of the hardwood pollen types (oak, hickory, elm, beech, walnut) from the dated material was found in the clay gyttja and tooth scrapings which indicated a vegetation consisting principally of spruce, grass, sedge, and composites. There is no evidence that animal punched through the peat, and therefore, date clearly postdates burial of the animal. 


\section{Lake Park series, Georgia}

Samples from peat deposit near Valdosta, Georgia $\left(30^{\circ} 42^{\prime} 33^{\prime \prime} \mathrm{N}\right.$ Lat, $83^{\circ} 13^{\prime} 5^{\prime \prime} \mathrm{W}$ Long). Coll. 1960 by E. Quarterman; and subm. by P. B. Sears.

\section{OWU-154. Profile I at 2 ft}

$$
\begin{aligned}
& 5710 \pm 120 \\
& 3760 \text { B.C. } \\
& 4990 \pm 150 \\
& 3040 \text { B.C. } \\
& 4740 \pm 95 \\
& 2790 \text { B.C. }
\end{aligned}
$$

OWU-155. Profile II at 2 ft

\section{OWU-156. Profile III at $4 \mathrm{ft}$}

Comment (P.B.S.): pollen samples from profiles indicate that all dates lie within period during which there was a decrease in arboreal pollen and an increase in ratio of oak to pine. Below these levels is a strongly marked decrease in arboreal pollen and a further increase in ratio of oak pollen to pine pollen.

\section{Refugee Road Beaver Site series, Columbus, Ohio}

Beaver-gnawed wood $(80 \%$ spruce, $15 \%$ willow or poplar, $5 \%$ juniper, id. by K. E. Phillips) recovered from foundation excavation on Refugee Road, SE Columbus, Ohio (39० $55^{\prime} \mathrm{N}$ Lat, $82^{\circ} 54^{\prime}$ W Long). Pollen analysis by Garrison (1967) indicates progressive decrease in arboreal pollen types from base of section to top (approx. $2.5 \mathrm{~m}$ ).

Predominant pollen types throughout section are spruce, fir, pine, sedge, and grass with small (less than 10\%) amounts of hardwood pollen. Coll. Oct. 1965 by G. H. Crowl, R. S. Baby, and J. G. Ogden, III; subm. by J. G. Ogden, III.

\section{OWU-177A. Beaver site spruce wood}

$13,125 \pm 475$

Sample heated to $500^{\circ} \mathrm{C}$ in stream of $\mathrm{N}_{2}$.

$$
\text { 11,175 B.C. }
$$

OWU-177B. Beaver site spruce wood $12,695 \pm 240$

Sample treated with $\mathrm{NaOH}$ and $\mathrm{HCl}$ only.

$$
10,745 \text { в.c. }
$$

\section{OWU-196. Beaver site peat 8-10"}

Peat overlying wood (OWU-177) at base of oxidized zone, 8 to 10 in. below surface.

OWU-197. Beaver site 28-30"

$13,200 \pm 480$

Peat associated with wood samples (OWU-177), 28 to 30 in. below surface. 
OWU-198. Beaver site clay gyttja 58-62"

$13,020 \pm 390$

11,070 B.c. ment (J.G.O. III): pollen data and ran, 58 to 62 in. below surface. Com$m e n t$ (J.G.O. III): pollen data and radiocarbon dates indicate that beaver
site represents short (less than 1000 r) time in central Ohio. Stratigraphy is ) occupation early in postglacial situ's in New England described by Kaye (1962) anilar to that of beaver though no bones were recovered, tooth (1962) and Ogden (1963). Alanimal was Castor canadensis. Find is similarks on wood indicate that Lights giant beaver (Castoroides Ohioenis) to, but older than Northern (Y-i26) and described in Prufer and Baby (1963).

\section{Vestaburg Bog series. Montealm County, Michigan}

Sediments from a core at Vestaburg Bog $\left(43^{\circ} 25^{\prime} \mathrm{N}\right.$ Lat, $84^{\circ} 53^{\prime} \mathrm{W}$ Long). Pollen analysis and sediment chemistry are reported in Gilliam et w. (1966). Coll. 1965 and subm. by R. O. Kapp.
OWU-199.
Core II: 8.00-8.25 m
$3145 \pm 240$
1200 B.C.
OWU-200A.
Core II: $10.25-10.50 \mathrm{~m}$
$6880 \pm 300$
(Sulfur present, poor methane yield)
4930 в.c.
OWU-200B. Core II: 10.25-10.50 m
$7980 \pm 250$
6030 B.C. $\mathrm{CO}$

\section{OWU-201. Core II: 11.00-11.20 $10,330 \pm 435$}

Comment (R.O.K.): OWU-11.20 m 8380 B.c.

mixed hardwood poll. OWU-199 is from upper part of postglacial characterizes colonization. OWU-200A for entry of beech into is a more probable date than OWU-201 is from low OW -201 is from lowermost gyttja overlying sharp transition to marl. Spruce pollen declines from $50 \%$ to $20 \%$ in this portion of core.

\section{Denmark Bog series, Morris County, New Jersey}

Denmark Bog ( $40^{\circ} 59^{\prime} \mathrm{N}$ Lat, $74^{\circ} 30^{\prime} \mathrm{W}$ Long) is located at alt 820 $\mathrm{ft}$ (MSL) in Copperas Mountains of northern New Jersey, ca. $20 \mathrm{mi} \mathrm{N}$ of Wisconsin glacial border. Test corings in deposit indicate maximum depth of 7 to $8 \mathrm{~m}$, of which the lower $4 \mathrm{~m}$ are interbedded sands and silts. Radiocarbon dates and pollen analysis (Phillips, 1966) indicate extended period of slow deposition from ca. $8700 \mathrm{yr}$ to $2700 \mathrm{yr}$ ago. Coll. Nov. 1965 and subm. by K. E. Phillips.

\section{OWU-186. Core DB-2 : $150-155 \mathrm{~cm}$}

$2290 \pm 165$

Principal arboreal pollen types include $\mathbf{3 4 0}$ B.c. 
pollen sum), birch $(10 \%)$, alder $(15 \%)$, hickory $(10 \%)$. Sedge and grass pollen make up $23 \%$ of total pollen sum at this level.

OWU-187. Core DB-2: $200-205 \mathrm{~cm}$

$6220 \pm 320$

Principal pollen types are oak $(9 \%)$, pine $(58 \%)$, hemlock $(5 \%)$, grass $(10 \%)$, and sedge $(10 \%)$.

OWU-188. Core DB-2 : $250-255 \mathrm{~cm}$

$8300 \pm 285$

Principal pollen types are pine $(62 \%)$, oak $(16 \%)$, grass $(8 \%)$, and sedge $(9 \%)$. Dated sample is just below main pine pollen maximum in core.

$11,500 \pm 360$

OWU-189. Core DB-2: $\mathbf{3 5 0 - 3 6 0} \mathrm{cm}$

9550 B.C.

Principal pollen types are pine $(40 \%)$, oak $(10 \%)$, spruce $(8 \%)$, and birch $(15 \%)$. Comment (J.G.O. III): late-glacial portion of pollen diagram (sedge and grass pollen up to $60 \%$ of the pollen sum) is only portion of core in which spruce pollen becomes dominant arboreal pollen type. "A" pollen zone is characterized by high percentages of pine and birch pollen. " $B$ " zone is principally pine pollen, and is recognized by decline of all nonarboreal pollen types to less than $15 \%$ of pollen sum. "C" pollen zone is indicated by decrease in pine pollen, with slight increase in oak, but primarily by an increase in grass, sedge, and alder pollen, presumably reflecting shoaling of the lake and closure of a bog mat. Upper meter of sediments include Equisetum and fern spores but no Pediastrum, as bog mat closed over and terrestric peats were formed. Sedimentation rates calculated from the four dates indicate that hickory first begins to make a continuous pollen record 3500 to $4000 \mathrm{yr}$ ago, and hemlock, which now grows on the NW- facing flank of Copperas Mountains, is continuously present in low (to $5 \%$ ) frequencies from ca. 10,500 yr ago. Entire profile is dominated by pine pollen and oak never exceeds $20 \%$ of pollen sum.

\section{Torren's Bog series, Licking County, Ohio}

Continuation of series of measurements first reported in OWU II from Torren's Bog in east-central Ohio $\left(40^{\circ} 21^{\prime} \mathrm{N}\right.$ Lat, $82^{\circ} 28^{\prime} \mathrm{W}$ Long). Preliminary pollen diagram from this deposit has been published in Field Guildbook G (Goldthwait et al., 1965b) of 7th INQUA Congress. Bog is located on Wisconsin terrace within $2 \mathrm{~km}$ of Wisconsin terminal moraine. Inasmuch as oldest samples from bog (OWU-92, 14,160 \pm 160 , OWU II) came from sediments ca. $50 \mathrm{~cm}$ above base of deposit, it is apparent that sedimentation began in this kettle shortly after retreat of late Wisconsin ice in this area. Detailed analysis of pollen and sediments from this core are to be published elsewhere.

$$
420 \pm 200
$$

OWU-207. Core TB-4: $25-35 \mathrm{~cm}$

Unconsolidated woody peat below rise in Ambrosia pollen. 
OWU-208. Core TB-4: 140-150 cm

Unconsolidated woody peat.

OWU-209. Core TB-4: $240-250 \mathrm{~cm}$

Unconsolidated woody peat.

OWU-210. Core TB-4: $350-360 \mathrm{~cm}$

OWU-211. Core TB-4: $450-460 \mathrm{~cm}$

Decomposed woody peat.

OWU-212. Core TB-4: $550-560 \mathrm{~cm}$

Decomposed woody peat with wood fragments.

OWU-213. Core TB-4: 650-660 $\mathrm{cm}$

Decomposed woody peat, wood fragments.

OWU-214. Core TB-4: $750-760 \mathrm{~cm}$

Decomposed woody peat.

OWU.215. Core TB-4: 850-860 cm
$1510 \pm 210$ A.D. 440

$3130 \pm 210$

1180 B.C.

$$
\begin{aligned}
& 3610 \pm 165 \\
& 1660 \text { в.C. } \\
& 4765 \pm 240 \\
& 2815 \text { B.C. }
\end{aligned}
$$

$5010 \pm 245$ 3060 B.C.

$7210 \pm 360$

5260 в.C.

$$
8640 \pm 320
$$

6690 B.c.

$$
10,960 \pm 410
$$

9010 B.C.

Decomposed woody peat. Samples OWU-214 and 215 bracket the replacement of pine pollen by oak pollen in the profile.

OWU-216. TB-4: $930-940 \mathrm{~cm}$

$10,520 \pm 410$

8570 B.c.

Grey-brown gyttja at contact with fibrous decomposed woody peat. Sample includes replacement of spruce pollen by pine pollen as dominant type in diagram.

\section{OWU-217. Core TB-4: $1070-1080 \mathrm{~cm}$}

$$
\begin{aligned}
& 11,405 \pm 640 \\
& 9455 \text { в. } .
\end{aligned}
$$

Homogeneous grey brown ooze, some small shells. Pollen spectrum at this level indicates a minor rise of oak pollen in the spruce pollen zone.

OWU-218. Core TB-4: 1150-1160

$11,860 \pm 860$

Grey-blue gyttja with lenses of coarse sand and fine gravel.

OWU-219. Core TB-4: $1250-1260 \mathrm{~cm}$

$12,800 \pm 600$

Stiff grey-blue clay gyttja with some medium $\mathbf{1 0 , 8 5 0}$ B.c. ment (J.G.O. III): nearly uniform sedimentation rate in lenses. Comcentury was calculated by a least-squares regression analysis programmed 
for an IBM 1620 computer. Replacement of spruce pollen by hardwood pollen is approx. bracketed by OWU-215 to OWU-217 and covers 115 cm of core. Time interval for this replacement is therefore ca. $1200 \mathrm{yr}$, which is similar to figure found for transition from conifer to hardwood pollen dominance at Silver Lake in west-central Ohio by Ogden (1966; and in press).

\section{ARCHAEOLOGIC SAMPLES}

\section{Apple Creek, Illinois}

Wood charcoal from hearth fires associated with components of Hopewellian phase of Pike tradition, Middle Woodland Period. Site is located in Lower Illinois River Valley $\left(39^{\circ} 22^{\prime} 9^{\prime \prime} \mathrm{N}\right.$ Lat, $90^{\circ} 32^{\prime} 20^{\prime \prime} \mathrm{W}$ Long) ca. $60 \mathrm{mi} \mathrm{N}$ of St. Louis, Missouri. Coll. Aug. 1963 and subm. by S. Streuver.

OWU-104. Apple Creek \# 17, Square $1850 \quad \delta \mathbf{C}^{14}+12.2 \%$

Oak charcoal (id. by B. Bruce) penetrated with numerous small rootlets. Sample too small for cellulose removal, and date indicates significant contamination by young carbon.

OWU.105A. Apple Creek \#13. Feature 367b A.D. 1375

$$
575 \pm 90
$$

OWU-105B. Apple Creek \#13. Feature 367b

$1490 \pm 175$

A.D. 460

The presence of small rootlets in OWU-105A indicated probable contamination with younger carbon. An additional sample was run as OWU-105B using the rootlet removal technique of Haynes (1966), and previously used in this lab. for OWU-92A (OWU II). Date is consistent with other Hopewellian materials run in this lab. (OWU-51, OWU II).

\section{Blue Rock, Pennsylvania}

Wood charcoal from late Woodland manifestation of Shenk's Ferry culture in Lower Sesquehanna valley (Nace component). Site is located at $39^{\circ} 59^{\prime} \mathrm{N}$ Lat, $76^{\circ} 28^{\prime} \mathrm{W}$ Long, $0.5 \mathrm{mi} \mathrm{S}$ of Washington Boro in Lancaster County, Pennsylvania. All samples were from hearth (OWU142) or midden (OWU-143 and -144) materials and were recovered within 24 in. of surface. All samples were thoroughly penetrated by roots, and had been dried so that hand separation was difficult and incomplete. Coll. July 1964, and subm. by C. Holzinger.

OWU-142A. Blue Rock Site A

Standard $\mathrm{NaOH}$ and $\mathrm{HCl}$ pre-treatment.

OWU-142B. Blue Rock Site A

Standard plus supplemental cellulose removal treatment after

$$
485 \pm 170
$$

A.D. 1465

$$
1215 \pm 345
$$

A.D. 735 Haynes (1966). 
OWU-143A. Blue Rock Site B

Standard pre-treatment.

$\delta \mathbf{C}^{14}+10.49^{\prime c c}$

OWU-143B. Blue Rock Site B

$\delta \mathbf{C}^{14}+\mathbf{0 . 4 2} \%$

Standard pre-treatment plus cellulose removal treatment after Haynes (1966).

OWU-143C. Blue Rock Site B

$\delta \mathbf{C}^{14}+\mathbf{8 . 0 4}$

Standard pre-treatment plus $5 \mathrm{~min}$ acetolysis reflux (9:1 Acetic anhydride: sulfuric acid).

\section{OWU-143D. Blue Rock Site B}

$230 \pm 175$

Standard pre-treatment plus one hour refluxing in acetolysis mixture.

\section{OWU-143E. Blue Rock Site B}

$560 \pm 150$

Standard pre-treatment plus one-hour refluxing in acetolysis mixture plus leaching with nine $200 \mathrm{ml}$ aliquots of acetone (3 more than nece sary to obtain a clear filtrate).

\section{OWU-144A. Blue Rock Site C}

Standard pre-treatment.

OWU-144B. Blue Rock Site C

standard pre-treatment plus cellu (1966, . Comment (J.G.O. III): moval techniques Where mon as test of cellulose removal techniques. Where modern rootlet contamination is less than $10 \%$ (as in OWU-142 and -144), cellulose removal treatment of Haynes (196ii) is adequate. In OWU-143, however, it was judged that rootlet particles amounted to approx. 40 to $50 \%$ of sample, in such a finely divided condition that hand separation was not practical. Under these conditions, the more rigorous acetolysis procedure (refluxing one hour) and leaching with acetone were necessary to reduce the concentration of young carbon. A sample loss of $60 \%$ is associated with this procedure.

\section{Mound City, Ohio}

Charcoal from excavations at Mound City Group Natl. Monument at Chillicothe, Ross County, Ohio ( $39^{\circ} 23^{\prime} \mathrm{N}$ Lat, $83^{\circ} 0^{\prime} \mathrm{W}$ Long). Previous sample from site gave age of $1772 \pm 53$ в.P. (OWU-51, OWU I).

\section{OWU-145. Mound City, Ohio}

Small charcoal sample near surface of mound, penetrated with numerous small rootlets. Coll. 1964 and subm. by R. S. Baby. Too small 
to process for cellulose removal. Modern age indicates significant contamination of sample by younger carbon.

OWU-172. Mound City \#I

$1890 \pm 100$

Charcoal fragments from midden area, $\mathrm{S}$ wall, feature 35B, RO-32, Grid C, depth $1.0 \mathrm{ft}$ in area of pottery concentration. Coll. Aug. 1963 and subm. by R. S. Baby.

OWU-173. Mound City \#2

$2100 \pm 150$

Oak charcoal from 2nd house, RO-32, beneath Mound 13, Posthole 96. Coll. Aug. 1963 and subm. by R. S. Baby.

\section{oWU-174. Mound City \#3}

A.D. 915

$1035 \pm 125$

Charcoal fragments with numerous rootlets, Mound 13, Posthole 53, 2nd layer below red-brown gravel. Sample too small to process for rootlet removal. Date is too young for occupation period represented, and it is therefore probable that some rootlet material remained after careful hand-picking.

OWU-146. Phillips mound, Ohio

$2305 \pm 535$

355 B.C.

Charred oak $\log$ (id. by G. W. Burns) from floor of house area in Phillips Mound, near Linworth, Franklin County, Ohio $\left(40^{\circ} 6^{\prime} \mathrm{N}\right.$ Lat, $83^{\circ} 3^{\prime}$ W Long). Artifacts indicate Adena occupation, ca. 300 в.c. Coll. 1964 by M. Phillips; subm. by R. S. Baby.

$4095 \pm 255$

OWU-147. Phillips mound, Ohio

2145 B.C.

Charcoal from Feature 2 of Phillips Mound. Comment (J.G.O. III): acetolysis procedure (see OWU-143, this date list) was applied to this sample for 15 minutes. Expected loss in dry weight did not occur, leading us to suspect formation of some insoluble acetate esters from treatment procedure. OWU-146 is considered by R. S. Baby to be appropriate in age for this culture, whereas date of OWU-147 is believed to be too old.

$1675 \pm 105$

OWU-148. Hambilton mound, Ohio

A.D. 275

Charred board from under Burials 3 and 4, Feature 2, of Hambilton

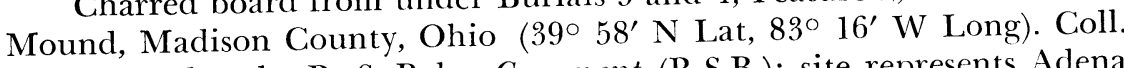
1964 and subm. by R. S. Baby. Comment (R.S.B.): site represents Adena culture, believed to be ca. 300 B.c. Date appears to be too young, but may represent a lingering tradition in this village.

\section{OWU-175. Riker Site. Tuscarawas County Ohio \\ $390 \pm 170$}

Charcoal fragments from late Prehistoric (Erie) Indian site on terrace, $\mathrm{N}$ side of Tuscarawas River $\left(40^{\circ} 26^{\prime} \mathrm{N}\right.$ Lat, $81^{\circ} 23^{\prime} \mathrm{W}$ Long). 
Sample collected from dark fill of village midden immediately over and around three burials made in a subsoil pit. Coll. 1964 by Sugar Creek Chapter of Archaeol. Soc. of Ohio; subm. by R. S. Baby. Estimated age A.D. 1100 to 1600 .

OWI-180. Chesser cave. Athens County, Ohio A.D. 1070

$880 \pm 140$

( 'harcoal from Sq. L, Chesser cave, level 0.5 to $1.0^{\prime}$, Vales Mills quadrangle $\left(7.5^{\prime}\right)$, Lee Twp. Athens County, Ohio $\left(39^{\circ} 13^{\prime} 15^{\prime \prime} \mathrm{N}\right.$ Lat, $82^{\circ} 16^{\prime} 8^{\prime \prime} \mathrm{W}$ Long). Coll. 1965 and subm. by O. H. Prufer. Comment (O.H.P.): sample rendered a value that proved unexpectedly late at first, but in light of our current beliefs of cultural development of the area, is, in fact, even more acceptable. Sample can best be understood in light of Graham village dates (OWU-183 and -184).

OWU-181. Morrison site, Ross County, Ohio

Charcoal from Pit E of Late Woodland Site, Ross County, Ohio (39 $12^{\prime}$ N Lat, $82^{\circ} 51^{\prime}$ W Long). Sample came from $6.0 \mathrm{ft}$. below surface and associated with charred corn. Coll. 1965 and subm. by O. H. Prufer. Comment (O.H.P.): additional charcoal from site has been processed by othel labs. The following additional dates have been obtained: GX0669, $50 \pm 120 ;$ GX0669b, $30 \pm 160 ; \mathrm{M}-1760,290 \pm 100 ; \mathrm{M}-1761,260 \pm 100$. From all dates we have calculated a probable mean value of A.D. 1730 which is in line with archaeological evidence and is supported by historical data from Christopher Gist Jour. of 1751 where he reports a small Delaware village at location of our site, and by Evans map of 1755 which show's location of this village and spot which we excavated.

\section{Graham village site, Hocking County, Ohio}

Two charcoal samples from features associated with early Baum Focus, Fort Ancient site $1 \mathrm{mi} \mathrm{S}$ of Logan, Ohio (39॰ $32^{\prime} \mathrm{N} \mathrm{Lat}, 82^{\circ} 23^{\prime} \mathrm{W}$ Long). Coll. 1965 by D. M. McKenzie; and subm. by D. M. McKenzie and O. H. Prufer.

\section{OWU-183. Feature 14, Graham Village}

\section{OWU-184. Feature 4, Graham Village}

Comment (O.H.P.): late date for OWU-184 may represent contamination from later sources as the hearth, although apparently undisturbed, was just beneath plow zone. It is not considered possible that site was in existence for time span represented by the two dates. Samples from Chesser cave (OWU-181, this date list) and OWU-183 from Graham village site represent essentially same time period although cultural assemblages are radically different. Graham village site is a Baum Focus, Fort Ancient village in Hocking Valley, while Chesser cave was in the 
hinterland of southeastern Appalachian region of state. We interpret this situation to mean that in the valley, Mississippification was beginning to take place at a fast clip while in the hinterland Late Woodland groups maintained themselves virtually untouched by new events taking place in major drainage systems. Results illustrate double tradition concept developed by Prufer et al. (1965) for McGraw site at later time level.

\section{OWU-185. Leimbach Fort, Lorain County, Ohio}

$2470 \pm 310$

Charcoal from posthole 1.0 to $1.3 \mathrm{ft}$ below surface, possibly part of a circular house, located in Brownhelm twp. Western Reserve (41 $22^{\prime}$ N Lat, $82^{\circ} 20^{\prime}$ W Long). Coll. 1965 by O. C. Shane, III and subm. by O. H. P. Comment (O.C.S.): ceramic affiliations of site indicate Early to Middle Woodland occupation. Date obtained supports ceramic evidence and is acceptable in view of other datings on similar cultural assemblages in midwest. Further discussion of these sites may be found in Prufer et al. (1966).

\section{CHECK SAMPLES}

\section{Turtle Creek, Warren County, Ohio 18,325 в.c.}

Spruce wood from $10 \mathrm{ft}$ deep in till, $100 \mathrm{yd} \mathrm{N}$ of Wisconsin boundry at intersection of Interstate 71 and State Rt. 123 in Warren County, Ohio. Coll. 1963 by D. Garner and J. Ernst and subm. by J. L. Forsyth. Comment (J.G.O. III): sample run as preparation check against OWU102 which gave 19,620 \pm 370 (OWU II). Dates are in good agreement.

\section{OWU-139A. U. Uper forest 6660 B.c. \\ OWU-139B. Upper forest bed, Squibnocket, Mass. $\quad \mathbf{8 8 2 0} \pm 180$ \\ Pine 6870 B.c.} pine wood (id. by G. W. Burns) from upper forest bed in peat deposit exposed in wave-cut cliff on island of Martha's Vineyard, Massachusetts ( $41^{\circ} 18^{\prime} \mathrm{N} \mathrm{Lat}, 70^{\circ} 46^{\prime} \mathrm{W}$ Long). Stratigraphy of site is described in Ogden (1963, Fig. 2). Beaver-gnawed wood from $80 \mathrm{~cm}$ deeper in section gave a $\mathrm{C}^{14}$ age of $11,352 \pm 211$ (OWU-6, OWU I). Comment (J.G.O. III): paired samples from same $\log$ were run to check sample preparation techniques. OWU-139A received usual pre-treatment of boiling in $2 \% \mathrm{NaOH}$ and $10 \% \mathrm{HCl}$. OWU-139B received an additional treatment of charring in stream of nitrogen at $500^{\circ} \mathrm{C}$ as a test of a procedure to distill off sulfur compounds. Results indicate that procedure is satisfactory and no appreciable fractionation occurs (see also OWU140B, OWU-224A and OWU-224B, this date list). Similar results are reported in Damon et al. (1966) for several samples of sequoia and bristlecone pine. 


\section{OWU-157. Kankakee Valley, Indiana}

$6805 \pm 150$

face of face of outwash along Kankakee River valley in abandoned pit in SW 1/4. NW 1/4, sec. 5, T32N, R5E of Porter County, Indiana. Sample was originally dated by U. S. Geol. Survey (USGS I) as W-59, 7990 \pm 200. Coll. and subm. by W. J. Wayne as interlaboratory check sample for Indiana Univ. Radiocarbon Dating Lab.

\section{OW U-158. Lake Eminence, Indiana}

$5115 \pm 145$

Wood from stream bank on

Cood from stream bank on E Fork of Mill Creek, in Hendricks $86^{\circ} 36^{\prime}$ Indiana NE 1/4, SW 1/4, sec. 11, T14N, R2W (39॰40' N Lat, $86^{\circ} 36^{\prime}$ W Long). Sample previously dated as LJ 290, $5000 \pm 250$ (La Jolla III). Coll. 1960 and subm. by W. J. Wayne as interlab. check sample for Indiana Univ. Radiocarbon Dating Lab. Sample charred in stream of nitrogen before combustion to $\mathrm{CO}_{2}$

Date lists:

\section{REFERENCFS}

I a Jolla III Hubbs, Bien, and Suess, 1963

OWU I Ogden and Hay, 1964

('WU II Ogden and Hay, 1965

I SGS I Suess, 1954 Black. R. F., and Reed, E. O., editors, 1965, Field Guidebook C, Upper Mississippi
Valley: 7th INQUA Congress.

Broecker, W. S. and Farrand, W. R., 1963, Radiocarbon age of the Two Creeks Forest Bed, Wisconsin: Geol. Soc. Am. Bull. v. 75, p. 795-802.

Damon, P. E., Long, A., and Grey, D. C., 1966, Fluctuation of atmospheric $C^{14}$ during the last six millennia: Jour. Geophys. Res., v. 71, p. 1055-1064.

Garrison, Gail C., in press, Pollen stratigraphy and age of an early postglacial beaver site near Columbus, Ohio: Ohio Jour. of Sci., v. 67.

Gillian,, J., Kapp, R. O., and Bogue, J., 1966, Vegetational history of Vestaburg Bog, Michigan: Papers, Mich. Acad. Sci., v. 52 (in press).

Goldthwait, R. P., Dreimanis, A., Forsyth, J. L. Karrow, P. F., and White, G. W., 1965, Pleistocene deposits of the Eric lobe: p. 85-97 in, The Quarternary of Press, x, 922 p. Goldthwait, R. P., editor, 1965, Field Guidebook G, Great Lakes-Ohio River Valley:
7th INQUA Congress. Haynes, C. V., 1966, Radiocarbon samples: chemical removal of plant contaminants:
Science, v. 151, p. 1391-1392.

Hubbs, C. L., Bien, G. S., and Suess, H. E., 1963, La Jolla natural radiocarbon measuremonts III: Radiocarbon, v. 5, p. 254-272.

Kaye, C. A., 1962, Early postglacial beavers in southeastern New England: Science, v.
$13 \%$, p. 906-907. Ogden. J. G., III, 1963, The Squibnocket Cliff Peat: radiocarbon dates and pollen
stratigraphy: Am. Jour. Sci., v. 261, p. 344-353.

of Silver 1966, Forest history of Ohio. I. radiocarbon dates and pollen stratigraphy of Silver Lake, Logan County, Ohio: Ohio Jour. Sci., v. 66, p. 387-400.

in the Great Lakes region approximaten evidence for a sudden change in climate Paleoccology, ed. by H. F Wright, 
Ogden, J. G., III, and Hay, R. J., 1964, Ohio Wesleyan

carbon measurements I: Radiocarbon, v. 6, p. 340-348. 1965, Ohio Wesleya

Radiocarbon, v. 7, p. 166-173.

Phillips, K. E., 1966, Pollen stratigraphy and forest history of Denmark Bog, Morris County, New Jersey: Abs. Sec. B, Ann. meeting, Ohio Acad. of Sci., Columbus.

Prufer, O. H., and Baby, R. S., 1963, Paleo-Indians of Ohio: Ohio Hist. Soc., Columbus, $134 \mathrm{p}$.

Prufer, O. H., McKenzie, H. H., Pi-Sunyer, O., Cutler, H. C., Yarnell, R. A., Parmalee, P. Y., and Stansbery, D. H., 1965, The McGraw Site: a study in Hopewellian Per., v. 4, 144 p.

schoewe, W. H., 1920, The origin and history of extinct Lake Calvin: Iowa Geol. Survey Ann. Report, v. 29, p. 49-222.

Schaffer, P. R., 1954, Extension of Tazewell glacial substage of western Illinois and eastern Iowa: Geol. Soc. Am. Bull., v. 65, p. 443-456.

Sears, P. B., 1966, Lake Lundy time: Science, v. 152, p. 386.

Suess, H. E., 1954, U.S. Geological Survey radiocarbon dates I: Science, v. 120, p. $467-$ 473. 